\title{
A new large capitosaur temnospondyl amphibian from the Early Triassic of Poland
}

Tomasz Sulej and Grzegorz Niedźwiedzki

Acta Palaeontologica Polonica 58 (1), 2013: 65-75 doi: http://dx.doi.org/10.4202/app.2011.0025

The Early Triassic record of the large capitosaurid amphibian genus Parotosuchus is supplemented by new material from fluvial deposits of Wióry, southern Poland, corresponding in age to the Detfurth Formation (Spathian, Late Olenekian) of the Germanic Basin. The skull of the new capitosaurid shows an "intermediate" morphology between that of Parotosuchus helgolandicus from the Volpriehausen-Detfurth Formation (Smithian, Early Olenekian) of Germany and the slightly younger Parotosuchus orenburgensis from European Russia. These three species may represent an evolutionary lineage that underwent a progressive shifting of the jaw articulation anteriorly. The morphology of the Polish form is distinct enough from other species of Parotosuchus to warrant erection of a new species. The very large mandible of Parotosuchus ptaszynskii sp. nov. indicates that this was one of the largest tetrapod of the Early Triassic. Its prominent anatomical features include a triangular retroarticular process and an elongated base of the hamate process.

Key words: Temnospondyli, Capitosauridae, Buntsandstein, Spathian, Olenekian, Triassic, Holy Cross Mountains, Poland.

Tomasz Sulej [sulej@twarda.pan.pl], Institute of Paleobiology, Polish Academy of Sciences, Twarda 51/55, PL-00-818 Warszawa, Poland;

Grzegorz Niedźwiedzki [grzegorz.niedzwiedzki@ebc.uu.se], Institute of Paleobiology, Polish Academy of Sciences, ul. Twarda 51/55, PL-00-818 Warszawa, Poland; current addresses: Department of Organismal Biology, Uppsala University, Norbyvägen 18A, 75236 Uppsala, Sweden and Department of Paleobiology and Evolution, Faculty of Biology, University of Warsaw, ul. Stefana Banacha 2, PL-02-097 Warszawa, Poland.

This is an open-access article distributed under the terms of the Creative Commons Attribution License (for details please see creativecommons.org), which permits unrestricted use, 
distribution, and reproduction in any medium, provided the original author and source are credited.

Forif Full text $(4,219.0 \mathrm{kB})$ 